\title{
PERSEPSI PENGUNJUNG TERHADAP AGROWISATA SAPI PERAH NUSA PELANGI DI KABUPATEN MALANG
}

\author{
Ahmad Ridwan \\ Fakultas Peternakan Universitas Brawijaya \\ Email : ridwan.sangmangkubumi@gmail.com \\ Siti Azizah \\ Fakultas Peternakan, Universitas Brawijaya \\ Anie Eka Kusumastuti \\ Fakultas Peternakan Universitas Brawijaya
}

\begin{abstract}
Research was conducted at Nusa Pelangi Dairy Agrotourism, Gubugklakah Village, Poncokusumo District, Malang Regency, starting from September $20^{\text {th }}$ to October 31 $1^{\text {st }}, 2017$. The purpose of this research were to identify profile, tourist characteristics, and tourist perception of Nusa Pelangi Dairy Agrotourism. Respondents were tourists who visited Nusa Pelangi Dairy Agrotourism with the age was more than 12 years old. The research used survey methode and analyzed by statistic descriptive and explorative descriptive. Data analysis showed that perception index of convenience and impression variable was 75,92 (high), perception index of sociability variable was 80,90 (high), perception index of use of facilities variable was 76,00 (high), perception index of access and linkage variable was 78,53 (high). It can be concluded that Nusa Pelangi Dairy Agroturism was a tourist attraction that located in Gubugklakah Tourist Village, Poncokusumo District, Malang Regency with temperature was 20 to $22^{\circ} \mathrm{C}$, so it was suitable for dairy agrotourism development. The tourist caracteristics at Nusa Pelangi Dairy Agrotourism age ranging from $12^{\text {th }}-21^{\text {st }}$ years old, generally as student, and lived in Malang Regency. Overall tourist had good perception towards Nusa Pelangi Dairy Agroturism.
\end{abstract}

Keywords: Perception, Nusa Pelangi, Dairy, Agrotourism 


\section{Pendahuluan}

Dariwisata telah menjadi industri yang mendunia dan juga 1 suatu bisnis yang semakin berkembang. Pariwisata menjadi faktor penting dalam pengembangan ekonomi karena kegiatannya mendorong perkembangan beberapa sektor ekonomi nasional. Dalam UU No 9 Tahun 1990 menyatakan bahwa salah satu tujuan penyelenggaraan kepariwisataan adalah untuk meningkatkan kesejahteraan dan kemakmuran rakyat.

Konsep pariwisata dibedakan menjadi beberapa macam, salah satunya adalah agrowisata. Agrowisata merupakan wisata berbasis agrokomplek yang mana memperkenalkan dunia pertanian, peternakan, dan perikanan kepada pengunjung sehingga pengunjung dapat mengetahui lebih jauh tentang seluk beluk kegiatan agrokomplek mulai dari hulu hingga hilir. Utama (2016) menjelaskan bahwa agrowisata atau wisata pertanian adalah sebagai rangkaian aktivitas perjalanan wisata yang memanfaatkan lokasi atau sektor pertanian mulai dari awal produksi hingga diperoleh produk pertanian dalam berbagai sistem dan skala dengan tujuan memperluas pengetahuan, pemahaman, pengalaman, dan rekreasi di bidang pertanian.

Agrowisata Sapi Perah Nusa Pelangi adalah salah satu agrowisata peternakan yang ada di Kabupaten Malang dan merupakan hibah Dinas Peternakan dan Kesehatan Hewan Kabupaten Malang kepada Kelompok Ternak Sapi Perah Nusa Pelangi, Desa Gubugklakah, Kecamatan Poncokusumo, Kabupaten Malang. Fasilitas wisata di Agrowisata Sapi Perah Nusa Pelangi diantaranya adalah kandang ternak yang berisi 13 ekor sapi betina dewasa dan enam ekor pedet, food court, auditorium, ruang pengolahan susu, gudang pakan, ruang kompos, dan tempat bermain.

Pengunjung Agrowisata Sapi Perah Nusa Pelangi, melalui persepsi yang dimiliknya, mempunyai peran yang penting dalam menilai pelayanan dan fasilitas di agrowisata tersebut. Menurut Sobur (2009) persepsi adalah pandangan atau pengertian, yaitu bagaimana seseorang memandang atau mengartikan sesuatu. 
Persepsi pengunjung terhadap fasilitas dan pelayanan Agrowisata Sapi Perah Nusa Pelangi yang meliputi aspek kenyamanan dan kesan, aspek keramahan, aspek penggunaan fasilitas, serta aspek akses dan linkage perlu untuk diketahui oleh pihak pengelola. Berdasarkan persepsi pengunjung tersebut, dapat dijadikan sebagai bahan evaluasi pengelola untuk meningkatkan pelayanannya terhadap pengunjung. Oleh sebab itu, penelitian tentang persepsi pengunjung terhadap Agrowisata Sapi Perah Nusa Pelangi ini perlu dilakukan.

\section{Teori dan Metode \\ Teori Persepsi}

Persepsi berlangsung saat seseorang menerima stimulus dari dunia luar yang ditangkap oleh organ-organ bantunya yang kemudian masuk ke dalam otak, kemudian terjadi proses berfikir yang akhirnya terwujud dalam sebuah pemahaman. Pemahaman ini yang kurang lebih disebut persepsi. Persepsi, sebelum terjadi pada manusia, diperlukan sebuah stimuli yang harus ditangkap melalui organ tubuh yang dapat digunakan sebagai alat bantunya untuk memahami lingkungannya. Alat bantu itu dinamakan alat indra. Indra yang saat ini secara universal diketahui adalah hidung, mata, telinga, lidah, dan kulit. Kelima indra tersebut memiliki fungsi-fungsi tersendiri.

Alat indra amatlah membantu dalam kehidupan seseorang. Ia dapat memberi sensasi. Sensasi adalah stimulan dari dunia luar yang dibawa masuk ke dalam sistem saraf. Hampir semua "hal" di dunia ini dibawa masuk oleh indra melalui sensasi. Adanya pemahaman informasi yang merupakan wujud interpretasi (memasukkan makna dari yang dirasakan/sensasi dengan yang ada terlebih dahulu) menjadikan sensasi yang awalnya hanya fisik bertambah sehingga terjadilah persepsi tersebut (Sarwono 2017).

\section{Teori Agrowisata}

Agrowisata atau wisata pertanian didefinisikan sebagai rangkaian aktivitas perjalanan wisata yang memanfaatkan lokasi 
atau sektor pertanian, mulai dari awal produksi hingga diperoleh produk pertanian dalam berbagai sistem dan skala dengan tujuan memperluas pengetahuan, pemahaman, pengalaman, dan rekreasi di bidang pertanian (Utama 2016).

Beberapa tahun terakhir sektor pertanian dipilih sebagai salah satu alternatif bagi dunia pariwisata. Tampaknya masyarakat cenderung meminati back to nature (kembali ke alam) sehingga sektor pertanian pun dipadukan dengan sektor-sektor lainnya dan dijadikan objek wisata (agrowisata) (Rukmana 2007).

\section{Metode}

Penelitian dilakukan di Agrowisata Sapi Perah Nusa Pelangi, Desa Gubugklakah, Kecamatan Poncokusumo, Kabupaten Malang pada bulan September hingga Oktober 2017. Metode dalam penelitian ini adalah survey dengan menggunakan analisis data deskriptif statistik dan deskriptif eksploratif. Teknik pengumpulan data adalah wawancara, pengisian kuisioner, dan observasi.

Populasi pada penelitian ini adalah pengunjung Agrowisata Sapi Perah Nusa Pelangi dengan kriteria pengunjung berusia dua belas tahun ke atas. Pertimbangannya bahwa pengunjung usia tersebut sudah dapat memberikan penilaian terhadap rangsang yang diterima oleh panca indranya. Pengunjung tersebut kemudian dibagi ke dalam kelompok 12 - 21 tahun dan $>21$ tahun. Sampel yang digunakan adalah 100 responden (unknown population) (Sugiyono 2015).

Instrumen pertanyaan dalam penelitian ini menggunakan 16 petanyaan. Setiap jawaban dihubungkan dengan pernyataan yang diungkapkan dengan jawaban berikut :

$\begin{array}{ll}\text { SS : sangat setuju ; } & \text { skor }=5 \\ \text { S : setuju ; } & \text { skor }=4 \\ \text { C : cukup ; } & \text { skor }=3 \\ \text { KS : kurang setuju ; } & \text { skor }=2 \\ \text { TS : tidak setuju ; } & \text { skor }=1\end{array}$


Persepsi Pengunjung Terhadap Agrowisata Sapi Perah Nusa Pelangi di Kab. Malang

Indeks persepsi dihitung dengan rumus di bawah ini

Nilai indeks $=\{(\mathrm{F} 1 \times 1)+(\mathrm{F} 2 \times 2)+(\mathrm{F} 3 \times 3)+(\mathrm{F} 4 \times 4)+(\mathrm{F} 5 \times 5)\} / 5$

Dimana :

F1 adalah jumlah responden yang menjawab sangat tidak setuju;

F2 adalah jumlah responden yang menjawab tidak setuju;

F3 adalah jumlah responden yang menjawab biasa saja;

F4 adalah jumlah responden yang menjawab setuju; dan

F5 adalah jumlah responden yang menjawab sangat setuju.

Angka indeks yang akan dihasilkan mulai dari 20 sampai 100 dengan rentang 80 . Indeks tersebut dikelompokkan menjadi tiga kriteria menggunakan kriteria tiga kotak (three boxes method) yang terbagi menjadi kategori rendah, sedang, dan tinggi (Wibowo, Rahadhini dkk. 2017). Rentang sebesar 80 dibagi 3 menghasilkan rentang sebesar 26,67 (80:3=26,67), sehingga didapatkan indeks kategori sebagai berikut :

$$
\begin{array}{ll}
20-46,67 & =\text { rendah } \\
46,68-73,35 & =\text { sedang } \\
73,36-100 & =\text { tinggi. }
\end{array}
$$

\section{Hasil dan Pembahasan}

\section{Profil Agrowisata Sapi Perah Nusa Pelangi}

Agrowisata Sapi Perah Nusa Pelangi adalah agrowisata sapi perah yang terletak di Desa Wisata Gubugklakah (DWG), Kecamatan Poncokusumo, Kabupaten Malang. DWG terletak pada ketinggian $900-1100 \mathrm{mdpl}$ dengan letak astronomis $7^{0} 21^{\mathrm{I}}-$ $7^{0} 31^{\mathrm{I}}$ Lintang Selatan dan $10^{0} 10^{\mathrm{I}}-11^{0} 40^{\mathrm{I}}$ Bujur Timur (lihat Foto 1). Suhu rata-sata di DWG adalah $20-22^{\circ} \mathrm{C}$. Luas lahan Agrowisata Sapi Perah Nusa Pelangi adalah $3000 \mathrm{~m}^{2}$.

Fasilitas wisata di Agrowisata Sapi Perah Nusa Pelangi diantaranya adalah kandang ternak yang berisi 13 ekor sapi betina dewasa dan enam ekor pedet (anak sapi), food court, auditorium, ruang pengolahan susu, gudang pakan, ruang kompos, dan 
tempat bermain.

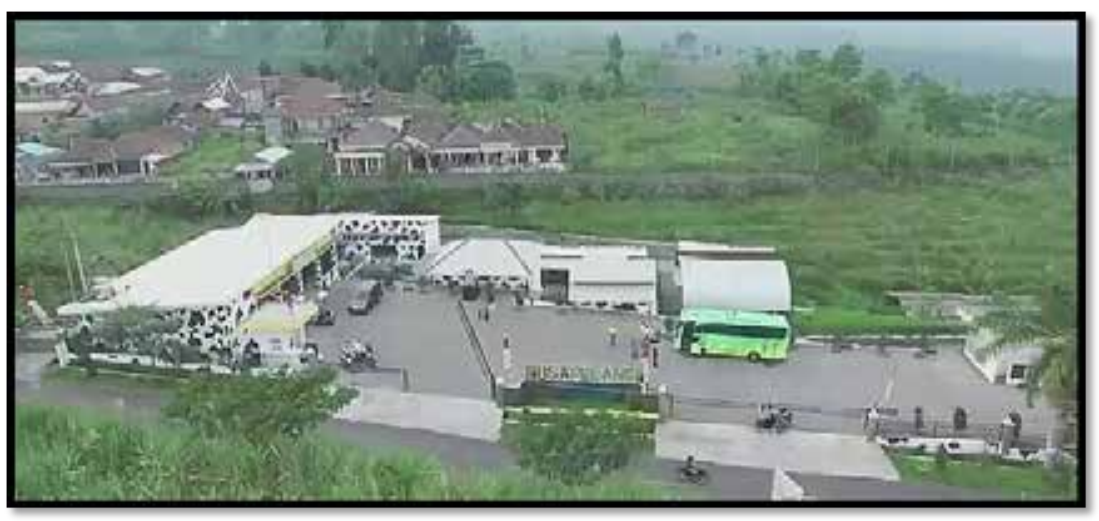

Foto 1. Agrowisata Sapi Perah Nusa Pelangi tampak atas

\section{Karakteristik Pengunjung}

Tabel 1. Karakteristik pengunjung Agrowisata Sapi Perah Nusa

\begin{tabular}{lcc}
\multicolumn{1}{c}{ Pelangi } & & \\
\hline $\begin{array}{l}\text { Karakteristik Pengun- } \\
\text { jung }\end{array}$ & Jumlah & \\
\hline Usia & 52 & $52 \%$ \\
$12-21$ & 48 & $48 \%$ \\
$>21$ & & \\
Jenis Kelamin & 50 & $50 \%$ \\
Laki - laki & 50 & $50 \%$ \\
Perempuan & & \\
Daerah Asal & 83 & $83 \%$ \\
Kabupaten Malang & 17 & $17 \%$ \\
Luar kabupaten Malang & & \\
Pekerjaan & 42 & $42 \%$ \\
Pelajar/Mahasiswa & & $2 \%$ \\
Pagawai Negeri Sipil & 2 & $18 \%$ \\
(PNS) & 18 & $21 \%$ \\
Karyawan & 21 & $10 \%$ \\
Wiraswasta & 10 & $7 \%$ \\
Ibu Rumah Tangga & 7 & \\
Lain-lain &
\end{tabular}

Sumber : Data primer diolah (2017)

$62 \quad$ JUMPA Volume 05, Nomor 01, Juli 2018 
Karakteristik pengunjung Agrowisata Sapi Perah Nusa Pelangi dalam penelitian ini dikelompokkan berdasarkan usia, jenis kelamin, daerah asal, dan pekerjaan. Pemaparan karakteristik pengunjung Agrowisata Sapi Perah Nusa Pelangi dapat dilihat pada Tabel 1.

Pengunjung paling banyak adalah pengunjung dengan usia 12 - 21 tahun. Usia tersebut tergolong usia remaja. Utama (2016) menjelaskan bahwa alasan yang menjadi motivasi liburan bagi remaja lebih kepada hal-hal yang bersifat hedonis atau bersenangsenang, serta lebih bersifat sosial, dengan alasan untuk bersama teman, mengunjungi teman, dan membuat pertemanan baru.

Jumlah pengunjung Agrowisata Sapi Perah Nusa Pelangi antara laki-laki dan perempuan sebanding. Hal ini disebabkan karena laki-laki dan perempuan sama-sama memiliki kebutuhan rekreasi. Premono dan Kunarso (2008) menjelaskan bahwa lakilaki dan perempuan memiliki kecenderungan yang sama dalam kebutuhan rekreasi.

Pengunjung yang berasal dari Kabupaten Malang adalah pengunjung yang paling banyak dalam berkunjung ke Agrowisata Sapi Perah Nusa Pelangi. Hal ini disebabkan karena mungkin kurangnya promosi yang dilakukan oleh pihak pengelola. Pihak pengelola hingga saat ini terus melakukan berbagai upaya dalam mempromosikan Agrowisata Sapi Perah Nusa Pelangi melalui media sosial, namun hasilnya masih belum sesuai harapan meskipun sudah ada perkembangan jumlah pengunjung sejak diresmikannya wisata tersebut. Usman dkk., (2012) menjelaskan bahwa mempromosikan wisata perlu untuk dilakukan agar masyarakat dapat mengetahui konsep-konsep yang ditawarkan.

Pengunjung yang berprofesi sebagai mahasiswa/pelajar adalah pengunjung paling banyak. Hal ini disebabkan karena Agrowisata Sapi Perah Nusa Pelangi menyajikan edukasi tentang peternakan sapi perah, sehingga mahasiswa/pelajar lebih tertarik untuk berkunjung dari pada pengunjung dengan profesi lain. Dwiputra (2010) menjelaskan bahwa wisatawan yang datang 
ke obyek wisata mayoritas adalah orang yang suka mencari pengalaman baru, yaitu mahasiswa dan pelajar.

\section{Persepsi Pengunjung terhadap Agrowisata Sapi Perah Nusa Pelangi Persepsi Pengunjung ditinjau dari Aspek Kenyamanan dan Kesan.}

Tabel 2. Penilaian persepsi pengunjung terhadap Agrowisata Sapi Perah Nusa Pelangi ditinjau dari aspek kenyamanan dan kesan.

\begin{tabular}{|c|c|c|c|c|c|c|c|c|c|c|c|c|c|}
\hline \multirow{2}{*}{ Jawaban } & \multirow{2}{*}{$\begin{array}{l}\text { Bo- } \\
\text { bot } \\
\text { Nilai }\end{array}$} & \multicolumn{10}{|c|}{ Jumlah Jawaban/Sub Variabel } & \multirow{2}{*}{ Total } & \multirow{2}{*}{ Skor } \\
\hline & & KEA & $\mathrm{KMN}$ & KBR & PT & PTD & KKB & KB & KT & $\mathrm{KP}$ & POP & & \\
\hline Sangat Setuju & 5 & 23 & 30 & 13 & 13 & 37 & 29 & 23 & 17 & 31 & 30 & 246 & 1230 \\
\hline Sstuju & 4 & 44 & 48 & 31 & 40 & 40 & 47 & 50 & 34 & 50 & 49 & 433 & 1732 \\
\hline Cukup & 3 & 26 & 19 & 28 & 35 & 21 & 15 & 18 & 27 & 17 & 14 & 220 & 660 \\
\hline Kurang & 2 & & & & & & & & & & & & \\
\hline Setuju & & 6 & 3 & 18 & 6 & 2 & 7 & 5 & 17 & 2 & 7 & 73 & 146 \\
\hline Tidak Setuju & 1 & 1 & 0 & 10 & 6 & 0 & 2 & 4 & 5 & 0 & 0 & 28 & 28 \\
\hline Jumlah & & 100 & 100 & 100 & 100 & 100 & 100 & 100 & 100 & 100 & 100 & 1000 & 3796 \\
\hline $\begin{array}{l}\text { Persepsi / } \\
\text { tingkat perseps }\end{array}$ & & $=379$ & $6 / 10 / 5$ & & $=$ & 75 & & & & & & Tin & \\
\hline
\end{tabular}

Sumber : Data primer diolah (2017)

Penilaian persepsi pengunjung ditinjau dari aspek kenyamanan dan kesan dibagi ke dalam 10 sub variabel yang terdiri dari sub variabel keamanan (KEA), kenyamanan (KMN), kebersihan $(\mathrm{KBR})$, penyediaan toilet $(\mathrm{PT})$, penyediaan tempat duduk (PTD), kebebasan dari kebisingan (KKB), kebebasan dari bau (KB), kondisi taman (KT), kondisi peternakan (KP), dan penyediaan olahan produk peternakan (POP). Hasil rekapitulasi kuisioner dan analisis data yang telah didapatkan dapat dilihat 
pada Tabel 2.

\section{A. Keamanan}

Persepsi pengunjung terhadap keamanan Agrowisata Sapi Perah Nusa Pelangi masuk dalam kategori tinggi dengan nilai indeks 76,4; sehingga agrowisata ini dapat dikatakan sebagai tempat wisata yang aman. Hal ini dikarenakan pengunjung merasa aman dari serangan ternak yang terdapat di Agrowisata Sapi Perah Nusa Pelangi; merasa aman dari adanya bencana alam; merasa aman dari tindakan kriminal; dan adanya petugas keamanan di lokasi agrowisata ini. Sejak Agrowisata Sapi Perah Nusa Pelangi diresmikan, belum ada laporan tindakan kriminal di agrowisata tersebut. Kholik (2014) menyatakan bahwa kenyamanan dan keamanan menjadi kondisi yang sangat penting dalam industri pariwisata. Aspek tersebut pada dua dekade terakhir telah menjadi isu dan mempunyai dampak yang sangat besar terhadap keberlangsungan aktivitas perjalanan dan pariwisata.

\section{B. Kenyamanan}

Persepsi pengunjung terhadap kenyamanan di Agrowisata Sapi Perah Nusa Pelangi tergolong dalam kategori tinggi dengan nilai indeks 81; sehingga agrowisata ini dapat dikatakan sebagai tempat wisata yang nyaman. Hal ini disebabkan karena pelayanan pengelola yang baik; fasilitas yang ditawarkan sesuai dengan harga tiket masuk; kondisi udara yang sejuk; dan pemandangan yang bagus. Gultom dkk. (2010) menyatakan bahwa aset yang penting untuk menarik kunjungan wisatawan adalah keaslian, keunikan, kenyamanan, dan keindahan alam. Oleh sebab itu, faktor kualitas lingkungan menjadi modal penting yang harus disediakan, terutama pada wilayah-wilayah yang dimanfaatkan untuk dijelajahi para wisatawan.

\section{Kebersihan}

Persepsi pengunjung terhadap kebersihan Agrowisata Sapi Perah Nusa Pelangi tergolong dalam kategori sedang dengan 
indeks persepsi 63,8; sehingga dapat dikatakan bahwa kebersihan di agrowisata ini adalah cukup. Hal ini disebabkan masih ada sampah yang berserakan. Pengelola kurang dalam menjaga kebersihan lingkungan di agrowisata ini. Beberapa pengunjung mengajukan komplain terhadap kebersihan di agrowisata tersebut, seperti: banyaknya sampah yang berserakan; banyak rumput liar; dan banyak daun yang berserakan. Nugraha (2017) menyatakan bahwa masyarakat sebagai pengelola hendaknya memberikan kenyamanan bagi para pengunjung serta kebersihan lingkungan, dengan adanya hal terebut maka wisatawan menjadi tertarik untuk melakukan kunjungan wisata.

\section{Penyediaan Toilet}

Persepsipengunjung terhadap penyediaan toilet berada pada kategori sedang dengan nilai indeks 69,6; sehingga bisa dikatakan bahwa penyediaan toilet di Agrowisata Sapi Perah Nusa Pelangi cukup. Hal ini dikarenakan kurang bersihnya air dan keadaan toilet yang kotor. Keluhan pengunjung mengenai penyediaan toilet adalah pada kebersihannya yang kurang terjaga. Wibowo dan Tim (2011) menyatakan bahwa fasilitas yang harus tersedia di tempat wisata adalah pertamanan, arena bermain anak-anak, fasilitas rekreasi, hiburan yang mengadung unsur pendidikan, hiburan yang mengandung unsur kebudayaan, tempat parkir cukup, informasi, toilet, tempat sampah, P3K, keamanan, sumber daya listrik, air bersih, pemadam kebakaran, sistem tata suara, sistem drainase, pelayanan makan-minum, dan akomodasi.

\section{E. Penyediaan tempat Duduk}

Persepsi pengunjung terhadap penyediaan tempat duduk oleh pengelola Agrowisata Sapi Perah Nusa Pelangi tergolong dalam kategori tinggi dengan nilai indeks 82,4 (Tabel 7); sehingga dapat dikatakan bahwa penyediaan tempat duduk di agrowisata ini sudah baik. Hal ini disebabakan karena jumlah tempat duduk sesuai dengan jumlah pengunjung, sehingga ketika pengunjung 
ingin duduk tidak perlu mengantri. Selain itu, tempat duduk yang terbuat dari kayu yang kuat, mudah dicari, dan nyaman saat digunakan. Kholik (2014) menjelaskan bahwa fasilitas fisik yang memadai di dalam dan di dekat kawasan wisata diperlukan untuk pengembangan yang efektif, salah satunya adalah tempat duduk.

\section{F. Kebebasan dari Kebisingan}

Handoko (2004) mengatakan bahwa pada abad sebelum ditemukannya peralatan modern yang mengeluarkan suara bising, kebisingan belum merupakan problem kehidupan dan masa sekarang memaksakan kepada kita untuk ikut memikirkan dan memecahkannya. Mengikuti evolusi dan perkembangan teknologi, kebisingan semakin terasa pengaruhnya.

Persepsi pengunjung terhadap kebebasan dari kebisingan di Agrowisata Sapi Perah Nusa Pelangi tergolong kategori tinggi dengan nilai indeks 78,8; sehingga dapat dikatakan bahwa Agrowisata Sapi Perah Nusa Pelangi bebas dari kebisingan. Hal ini dikarenakan lokasi agrowisata tidak berada pada jalan yang ramai, tidak terdengar suara mesin di sekitar lokasi, tidak terdengar suara keributan, dan lokasi berada di pedesaan yang sepi.

\section{G. Kebebasan dari Bau}

Persepsi pengunjung terhadap kebebasan bau di Agrowisata Sapi Perah Nusa Pelangi tergolong kategori tinggi dengan nilai indeks sebesar 76,6; sehingga dapat dikatakan bahwa agrowisata ini bebas dari bau. Hal ini disebabkan karena tidak tercium aroma sampah, limbah rumah tangga dan limbah pertanian di sekitar lokasi agrowisata. Aroma bau kotoran ternak hanya tercium di sekitar lokasi kandang ternak, namun hal ini masih dapat ditoleransi oleh pengunjung. Gultom dkk. (2010) menjelaskan bahwa hadirnya bau akan membuat wisatawan merasa terganggu dalam melakukan aktifitas wisata. 


\section{H. Kondisi Taman}

PersepsipengunjungterhadapkondisitamandiAgrowisata Sapi Perah Nusa Pelangi tergolong dalam kategori sedang dengan skor indeks sebesar 68,2; sehingga dapat dikatakan bahwa kondisi taman di agrowisata ini cukup. Hal ini dikarenakan beberapa taman yang ada di agrowisata ini kurang mendapat perawatan oleh pengelolanya. Banyak rumput-rumput liar yang tumbuh dan tanaman yang seharusnya dipotong tidak dipotong, sehingga terlihat kurang bagus. Karyono (2007) menjelaskan bahwa fungsi taman bukan hanya untuk tujuan pemenuhan kenyamanan visual saja, melainkan untuk memenuhi aspek-aspek kenyamanan fisik yang lainnya seperti spasial, audial dan termal.

\section{J. Kondisi Peternakan}

Persepsi masyarkat terhadap Agrowisata Sapi Perah Nusa Pelangi tergolong kategori tinggi dengan nilai indeks 82; sehingga dapat dikatakan bahwa kondisi peternakan agrowisata ini sudah dianggap baik. Hal ini dikarenakan peternakan di agrowisata ini sudah menerapkan sistem pemerahan modern/menggunakan mesin perah (lihat Foto 2); terdapat sapi perah dengan fase fisiologis yang berbeda; serta kondisi kandang yang digunakan didisain menarik dan terbuat dari bahan berkualitas baik. Nangoy dan Sela (2016) menjelaskan bahwa agrowsiata sapi perah adalah penggunaan industri peternakan sebagai kawasan wisata untuk sarana rekreasi, yang dikembangkan dengan ilmu pengetahuan, guna mempertahankan dan mengembangkan dunia pariwisata. Tujuan lainnya juga menjadi promosi dalam hal ini produk peternakan, memberikan signal bagi peluang pengembangan diversifikasi produk agribisnis dan berarti pula dapat menjadi kawasan pertumbuhan baru daerah sektor peternakan. 


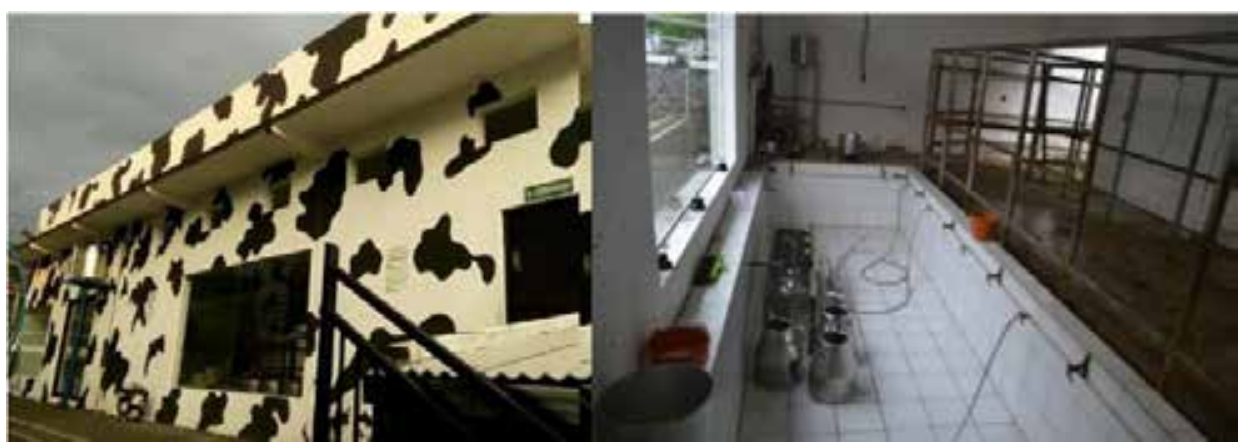

Foto 2: Tempat pemerahan menggunakan mesin pemerah modern

\section{K. Penyediaan Olahan Produk Peternakan}

Persepsi pengunjung terhadap penyediaan produk olahan peternakan di Agrowisata Sapi Perah Nusa Pelangi tergolong kategori tinggi dengan nilai indeks 80,4; sehingga dapat dikatakan bahwa penyediaan produk di agrowisata ini sudah baik. Hal ini dikarenakan produk yang ditawarkan bervariasi, dikemas menarik, dan selalu tersedia di food court (lihat Foto 3). Usman dkk. (2012) menjelaskan bahwa pengembangan agrowisata pada konsep universal dapat ditempuh melalui diversifikasi dan peningkatan kualitas sesuai dengan persyaratan yang diminta konsumen dan pasar global. Penataan dengan konsep uniqueness perlu dilakukan dengan salah satunya, menawarkan konsumen produk spesifik yang bersifat unik.

\section{Persepsi Pengunjung ditinjau dari Aspek Keramahan}

Penilaian persepsi pengunjung ditinjau dari Aspek Keramahan dibagi ke dalam dua sub variabel yang terdiri dari sub variabel Kecocokan Tempat untuk Digunakan Bersama (KTB) dan Keramahan Pengelola (KP). Hasil rekapitulasi kuisioner dan analisis data yang telah didapatkan dapat dilihat pada Tabel 3. 
Tabel 3. Penilaian persepsi pengunjung terhadap Agrowisata Sapi Perah Nusa Pelangi ditinjau dari Aspek Keramahan

\begin{tabular}{|c|c|c|c|c|c|}
\hline \multirow[t]{2}{*}{ Jawaban } & \multirow{2}{*}{$\begin{array}{l}\text { Bo- } \\
\text { bot } \\
\text { Nilai }\end{array}$} & \multicolumn{2}{|c|}{$\begin{array}{c}\text { Jumlah Jawaban Sub } \\
\text { Variabel }\end{array}$} & \multirow{2}{*}{$\begin{array}{l}\text { Total Jawa- } \\
\text { ban }\end{array}$} & \multirow[t]{2}{*}{ Skor } \\
\hline & & KTB & $\mathrm{KP}$ & & \\
\hline Sangat Setuju & 5 & 49 & 23 & 72 & 360 \\
\hline Setuju & 4 & 41 & 39 & 80 & 320 \\
\hline Cukup & 3 & 10 & 23 & 33 & 99 \\
\hline Kurang Setuju & 2 & 0 & 15 & 15 & 30 \\
\hline Tidak Setuju & 1 & 0 & 0 & 0 & 0 \\
\hline Jumlah & & 100 & 100 & 200 & 809 \\
\hline Persepsi / tingkat persepsi & & & $2 / 5$ & $=\mathbf{8 0 , 9}$ & Tinggi \\
\hline
\end{tabular}

Sumber : Data primer diolah (2017)

Keterangan

Skor $=$ Bobot Nilai $X$ Total Jawaban

\section{A. Tempat yang Cocok Digunakan untuk Berkumpul Bersama}

Azahro dan Yuliastuti (2013) menjelaskan bahwa dimana ada kehidupan pasti berkaitan dengan ruang untuk kehidupan, khususnya ruang publik yang digunakan untuk bersamasama dalam menjalankan kehidupan sehari-hari. Persepsi pengunjung terhadap tempat yang cocok digunakan untuk berkumpul bersama di Agrowisata Sapi Perah Nusa Pelangi tergolong kategori tinggi dengan nilai indeks 87,8; sehingga dapat dikatakan bahwa penyedian tempat yang cocok digunakan untuk berkumpul bersama oleh pengelola agrowisata ini sudah baik. Hal ini dikarenakan adanya fasilitas-fasilitas yang dapat digunakan secara bersama-sama oleh pengunjung, seperti: Café/Food court, tempat bermain anak, dan kandang yang dapat digunakan untuk memberi makan sapi bersama kelaurga atau teman. 


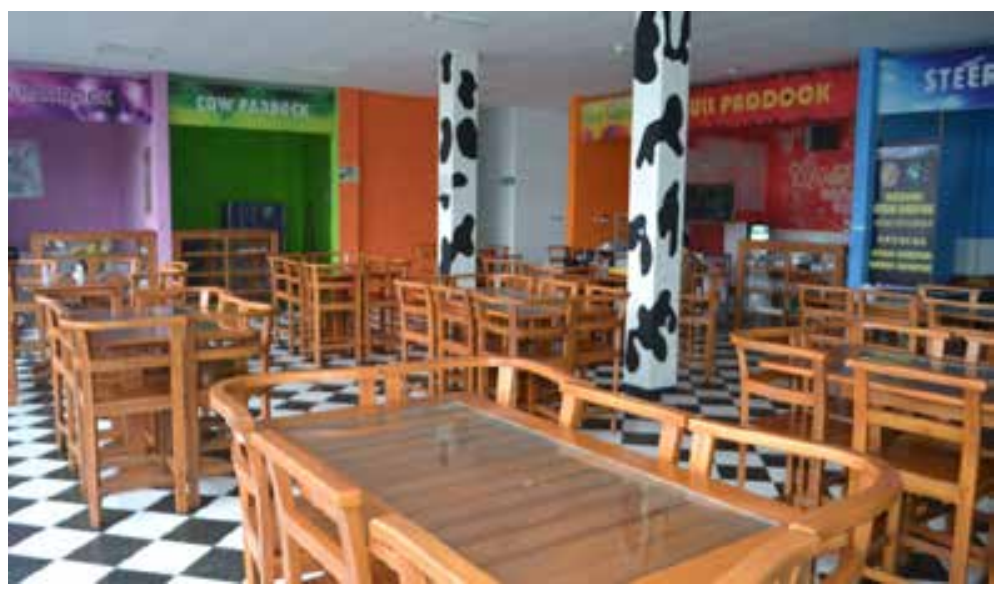

Foto 3: Food Court

\section{B. Keramahan Pengelola}

Atmojo (2012) menjelaskan bahwa keramahan pengelola adalah sikap positif dan perilaku terhormat yang harus ditunjukkan oleh pengelola kepada setiap Pengunjung. Persepsi pengunjung terhadap keramahan pengelola di Agrowisata Sapi Perah Nusa Pelangi tergolong kategori tinggi dengan nilai indeks 74. Hal ini disebabkan karena pengelola menunjukkan keramahannya kepada pengunjung; pengelola membantu pengunjung ketika diminta bantuan' dan pengelola menyambut pengunjung dengan baik.

\section{Persepsi Pengunjung ditinjau dari Aspek Penggunaan dan Fasilitas}

Tabel 4. Penilaian persepsi pengunjung terhadap Agrowisata Sapi Perah Nusa Pelangi ditinjau dari aspek penggunaan fasilitas

\begin{tabular}{lcccc}
\hline \multicolumn{1}{c}{ Jawaban } & Bobot Nilai & Frekuensi (F) & Persentase (\%) & $\begin{array}{c}\text { Bobot Nilai X } \\
\text { Frekuensi }\end{array}$ \\
\hline Sangat Setuju & 5 & 23 & 23 & 115 \\
Setuju & 4 & 43 & 43 & 172 \\
Cukup & 3 & 26 & 26 & 78 \\
Kurang Setuju & 2 & 7 & 7 & 14 \\
Tidak Setuju & 1 & 1 & 1 & 1 \\
\multicolumn{1}{c}{ Jumlah } & & 100 & 100 & 380 \\
\hline \multicolumn{2}{c}{ Nilai Indeks Persepsi } & $380 / 5=76$ & Kategori : & Tinggi \\
\hline
\end{tabular}

Sumber : Data primer diolah (2017) 
Persepsi pengunjung terhadap agrowisata Sapi Perah Nusa Pelangi ditinjau dari aspek penggunaan fasilitas tergolong kategori tinggi dengan nilai indeks 76 (Tabel 4). Hal ini disebabkan karena fasilitas yang ada jumlahnya sebanding dengan jumlah pengunjung sehingga pengunjung tidak perlu antri lama ketika ingin menggunakan fasilitas wisata. Fasilitas yang ada juga dapat digunakan sebagai sarana edukasi yang dapat mengembangkan kemampuan pengunjung dilihat dari segi kognitif, afektif, dan psikomotor. Gurindawangsa (2017) menjelaskan bahwa melihat dari sektor pertanian yang dominan dan sektor pariwisata yang mulai berkembang, maka sangatlah cocok jika dua sektor tersebut digabungkan menjadi satu atraksi wisata yang menarik dan beredukasi yaitu agrowisata.

\section{Persepsi Pengunjung ditinjau dari Aspek Akses dan Linkage}

Penilaian persepsi pengunjung terhadap Agrowisata Sapi Perah Nusa Pelangi ditinjau dari Aspek Akses dan Linkage diukur dengan menggunakan tiga sub variabel, yaitu Akses dengan Kendaraan (AK), Akses dengan Jalan Kaki (AJK), dan Linkage di dalam Tempat Wisata (LTW). Hasil penilaian persepsi pengunjung terhadap Agrowisata Sapi Perah Nusa Pelangi ditinjau dari aspek Akses dan Linkage tersaji pada Tabel 5.

Tabel 5. Penilaian persepsi pengunjung terhadap Agrowisata Sapi Perah Nusa Pelangi ditinjau dari aspek akses dan linkage

\begin{tabular}{lccccc}
\hline \multirow{2}{*}{ Jawaban } & \multirow{2}{*}{$\begin{array}{c}\text { Bobot } \\
\text { Nilai }\end{array}$} & \multicolumn{3}{c}{ Jumlah Jawaban Sub Variabel } & \multirow{2}{*}{$\begin{array}{c}\text { Jumlah Jawaban } \\
\text { X Bobot Nilai }\end{array}$} \\
\cline { 3 - 5 } Sangat Setuju & 5 & 52 & 10 & 39 & 505 \\
Setuju & 4 & 37 & 37 & 45 & 476 \\
Cukup & 3 & 10 & 25 & 13 & 144 \\
Kurang Setuju & 2 & 1 & 17 & 3 & 42 \\
Tidak Setuju & 1 & 0 & 11 & 0 & 11 \\
\hline \multicolumn{2}{c}{ Jumlah } & 100 & 100 & 100 & 1175 \\
Persepsi / tingkat persepsi & \multicolumn{5}{l}{$=1178 / 3 / 5$} \\
\hline
\end{tabular}

Sumber : Data primer diolah (2017) 


\section{A. Akses dengan Kendaraan}

Persepsi pengunjung terhadap akses dengan kendaraan ke Agrowisata Sapi Perah Nusa Pelangi tergolong tinggi dengan nilai indeks sebesar 88; sehingga dapat dikatakan bahwa akses dengan kendaraan ke agrowisata ini sudah baik. Hal ini disebabkan karena tempat wisata mudah dijangkau dengan kendaraan umum, kendaraan roda dua, kendaraan roda empat, dan bis. Yanti dkk. (2016) menjelaskan bahwa lokasi tempat wisata haruslah mudah dijangkau atau memiliki aksesibilitas yang baik mencakup jarak maupun ketersediaan moda transportasi darat, udara, laut yang mudah dan murah.

\section{B. Akses dengan Jalan Kaki}

Prijadi dkk. (2014) menjelaskan bahwa para wisatawan yang tertarik terhadap potensi pariwisata atau yang berminat mengenali kawasan tersebut tentunya tidak segan melakukan kunjungan terutama dengan berjalan kaki, atau wisata jalanjalan sambil melihat-lihat keadaan (sight seeing), karena dengan berjalan kaki akan lebih banyak yang dapat dilihat, dilakukan dan sehat bagi wisatawan.

Persepsi pengunjung terhadap akses dengan jalan kaki ke Agrowisata Sapi Perah Nusa Pelangi tergolong kategori sedang dengan nilai indeks 63,6; sehingga dapat dikatakan bahwa akses dengan jalan kaki menuju agrowisata ini cukup. Hal ini disebabkan oleh jalan yang sempit, tidak rata, kurang aman dan kurang cocok bila digunakan oleh orang cacat (tuna netra dan cacat kaki).

\section{Linkage di dalam Tempat Wisata}

Persepsi pengunjung terhadap linkage di dalam tempat wisata Agrowisata Sapi Perah Nusa Pelangi tergolong kategori tinggi denga nilai indeks 84; sehingga dapat dikatakan bahwa linkage di dalam tempat wisata Agrowisata Sapi Perah Nusa Pelangi baik. Hal ini disebabkan oleh jalan yang tidak berlubang, jalan berpaving, dan luas. Yuliastuti dan Fatchurochman (2012) menjelaskan bahwa kriteria kualitas jalan yang tergolong baik 
apabila kondisi jalan tidak mengalami kerusakan sehingga pengguna jalan merasa nyaman dan aman.

\section{Simpulan}

AgrowisataSapiPerahNusaPelangiadalahobjek wisatayang terletak di Desa Wisata Gubugklakah, Kecamatan Poncokusumo, Kabupaten Malang. Harga tiket masuk ke Agrowisata Sapi Perah Nusa Pelangi terdiri dari empat paket. Fasilitas-fasilitas yang ada di Agrowisata Sapi Perah Nusa Pelangi adalah : Cafe/food court, tempat bermain anak, ruang studio, ruang pemerahan, kandang sapi induk, kandang anak sapi, ruang pemerahan, ruang pakan, ruang kompos, dan patung sapi. Karakteristik pengunjung Agrowisata Sapi Perah Nusa Pelangi didominasi oleh usia remaja (12 - 21 tahun) dan dewasa (> 21 tahun), rata-rata berprofesi sebagai pelajar dan mahasiswa, serta berdomisili di Kabupaten Malang. Persepsi pengunjung ditinjau dari aspek kenyamanan dan kesan, keramahan, penggunaan fasilitas, dan akses dan linkage tergolong tinggi yang artinya bahwa pengunjung telah memberikan persepsi yang baik

\section{DAFTAR PUSTAKA}

Atmojo, A.R.D. 2012. Persepsi Pengunjung terhadap Kualitas Pelayanan pada Museum Mulawarman Tenggarong. Jurnal Eksis. 8 (1) : 2123 - 2127.

Azahro, M., Yuliastuti, N. 2013. Kajian Kehidupan Masyarakat Kampung Lama sebagai Potensi Keberlanjutan Lingkungan Pemukiman Kelurahan Gabahan Semarang. Jurnal Teknik PWK. 2 (3) : 481 - 490.

Dwiputra, R. 2013. Preferensi Wisatawan terhadap Sarana Wisata di Kawasan Wisata Alam Erupsi Merapi. Jurnal Perencanaan Wilayah dan Kota. $24(1): 35-48$.

Gultom, E.R., Wahyuningsih, H., dan Soemaryono, Y. 2010. Analisis Daya Dukung Lingkungan Perairan terhadap Daya Tarik Wisata di Kecamatan Ajibata Kabupaten Toba Samosir. Jurnal Perencanaan Wilayah dan Kota. 1 (4) : 10-18.

Gurindawangsa, S.A., Topowijono, Supriono. 2017. Analisis Strategi Pengembangan Produk Agrowisata. Jurnal Administrasi Bisinis 
(JAB). $51: 141-150$.

Karyono, T.H. 2007. Fungsi Ruang Hijau Kota Ditinjau dari Aspek Keindahan, Kenyamanan, Kesehatan, dan Penghematan Energi. Jurnal Teknik Lingkungan. 6 (3) : $452-457$.

Kholik, W. 2014. Kajian Kenyamanan dan Keamanan Wisatawan di Kawasan Pariwisata Kuta Lombok. JUMPA. 1(1) : 23 - 42.

Nangoy, W.M. dan Sela, R.L.E. 2016. Optimalisasi Konsep Building as Nature dari Pendekatan Arsitektur Organik pada Kawasan Industri Peternakan Berkonsep Agrowisata. 13 (1) : 56 - 67.

Premono, T.B. dan Kunarso, A. 2008. Pengaruh Perilaku Pengunjung terhadap Jumlah Kunjungan di Taman Wisata Alam Punti Kayu Palembang. Jurnal Penelitian Hutan dan Konversi Alam. 5 (5) : 423 $-433$.

Prijadi, R., Sangkertadi, Tarore, R.C. 2014. Pengaruh Permukaan Jalur Pedestrian terhadap Kepuasan dan Kenyamanan Pejalan Kaki di Pusat Kota Manado. Meida Matrasain. 11 (1) : 43 - 54.

Rukmana, R. 2007. Prospek Agrobisnis dan Teknik Budidaya Lengkeng. Jakarta : Agromedia Pustaka

Sarwono, S.W. 2017. Pengantar Psikologi Umum. Jakarta : Raja Grafindo Persada.

Sugiyono. 2015. Metode penelitian kuantitatif, kualitatif, dan RED. Bandung: Alfabeta.

Utama, G.B., 2016. Pengantar Industri Pariwisata. Yogyakarta: Deepublish

Usman, Hakim, L., Malik, I., 2012. Strategi Pemerintah Daerah dalam Pengembangan Agrowisata di Kabupaten Bantaeng. Otoritas. 2 (2) : 191-200.

Wibowo, G., Rahadhini., Sunarso. 2017. Analisis Pengaruh Kualitas Produk dan Kualitas Pelayanan terhadap Kepuasan Konsumen dalam Membentuk Niat Beli Ulang. Jurnal Ekonomi dan Kewiarausahaan. 17 (1) : 1-9.

Yanti, N.K.D., Lila, K.A., Yusiana, L.S. 2016. Studi Potensi Subak Tanah Yeng sebagai Kawasan Agrowisata di Desa Sedang, Kecamatan Abiansemal, Kabupaten Badung. E_Jurnal Arsitektur Lansekap. 2 (2) : 155 - 164.

Yuliastuti, N. Fachurochman, A. 2012. “Pengaruh Perkembangan Lahan Terbangun terhadap Kualitas Lingkungan Pemukiman." Jurnal Pretisipasi. 9 (1) : $10-16$. 


\section{Profil Penulis}

Ahmad Ridwan, S.Pt adalah alumni Program Studi Peternakan, Fakultas Peternakan, Universitas Brawijaya, Malang. Menyelesaikan Pendidikan Sarjana pada tahun 2018

Dr. Siti Azizah, S.Pt., M.Sos., M.Commun. adalah Dosen Sosial Ekonomi Peternakan, Fakultas Peternakan, Universitas Brawijaya, Malang. Ia menyelesaikan pendidikan sarjana di Fakultas Peternakan Universitas Brawijaya pada tahun 1997. Pendidikan Magister ia selesaikan di Program Studi Sosiologi, Fakultas Pertanian, Universitas Brawijaya pada tahun 2004 dan Master Communication, di University of Queensland Australia pada tahun 2005. Pendidikan Doktor ia selesaikan di Program Studi Sosiologi, Fakultas Pertanian, Universitas Brawijaya pada tahun 2014.

Anie Eka Kusumastuti, S.Pt., M.Sc. adalah Dosen dan Ketua Minat Sosial Ekonomi Peternakan Universitas Brawijaya pada tahun 2004, Malang. Ia menyelesaikan Pendidikan Sarjana di Fakultas Peternakan Universitas Brawijaya, sendangkan Pendidikan Magister ia selesaikan di Program Studi Magister Ilmu Ternak, Universitas Brawijaya pada tahun 2012 dan Magister of Science Prince of Songkla University (Agricultural and Coastal Resources Development) Thailand pada tahun 2012. 